\title{
Physician Resistance and the Forging of Public Healthcare: A Comparative Analysis of the Doctors' Strikes in Canada and Belgium in the 1960s
}

\author{
GREGORY P. MARCHILDON and KLAARTJE SCHRIJVERS*
}

\begin{abstract}
Organised medicine in a number of advanced industrial countries resisted the post-war trend toward more state involvement in the funding and organisation of medical care. While there were eight doctors' strikes during the peak of reform efforts in the 1960s, two of the most prolonged and bitter struggles took place in Canada and Belgium. This comparative analysis of the two strikes highlights the philosophy, motives, and strategies of organised medicine in resisting stateled reform efforts. Although historical and institutional contexts in the two countries differed, organised medicine in Canada and Belgium thought and responded in very similar ways to the perceived threat of medical insurance reform. While the perception of who won and who lost the respective doctors' strikes differed, the ultimate impact on the trajectory of public healthcare on the medical profession was remarkably similar. In both countries, the strike would have a long-standing impact on future reform efforts, particularly efforts to reform physician remuneration in order to facilitate more effective primary healthcare.
\end{abstract}

Keywords: Doctors' Strike; Canada; Belgium; Saskatchewan; 1960s; Organised Medicine; Fee-for-Service; Medical Liberalism; Edmond Leburton; Tommy Douglas

\section{Introduction}

In the post-war era, there was a pronounced trend towards state intervention in the establishment of universal public healthcare systems in market-based advanced industrial countries. This movement was particularly marked in Western Europe, but was also evident in Canada, Australia, and New Zealand. However, organised medicine often opposed this development, worrying that its closer proximity to the state through changes

(C) Gregory P. Marchildon and Klaartje Schrijvers, 2011.

*Gregory P. Marchildon, Canada Research Chair in Public Policy and Economic History, JohnsonShoyama Graduate School of Public Policy, University of Regina, 110-12 Research Drive, Regina,
Saskatchewan, Canada S4S 0A2. Corresponding author. Email: greg.marchildon@uregina.ca

Klaartje Schrijvers, Professor in Political History at the RITS (Film and Dramaschool Brussels), Independent Artist and Researcher, 21 Avenue Jean Volders, 1060 Brussels, Belgium 
in payment systems might, over time, reduce physician income and diminish professional autonomy. Between 1960 and 1968, there were a total of eight doctors' strikes in response to the state's increased role in healthcare. ${ }^{1}$ Two of the most sustained and threatening strikes occurred in Canada and Belgium. In 1962, Canadian doctors organised a twenty-three-day strike, while two years later, Belgian doctors launched an eighteenday strike. In both countries, these strikes re-shaped the subsequent design of universal healthcare, preserving the centrality of a fee-for-service contractual model of physician engagement with patients and the state as opposed to a salaried-employment model.

A comparative analysis of the Canadian and Belgian strikes elucidates some of the common elements of these more extreme cases of physician resistance to collectively funded and administered healthcare. ${ }^{2}$ These included a commitment to what we call 'medical liberalism', an individualistic philosophy that was opposed to at least some of the more collectivist assumptions underpinning governing parties that were expanding the welfare state. Drawing from the Canadian and Belgian cases, this medical liberalism was characterised by doctor-patient confidentiality, free choice of doctor by the patient, non-interference by state administrators in a doctor's individual clinical judgment, and fees set by individual doctors (as opposed to the state) in order to preserve the privacy and privileged nature of the doctor-patient relationship.

To protect their interests, physicians established new organisations, or refashioned existing organisations, into 'trade unions' capable of opposing governments through collective action including the credible threat of strike. Disciplined in their public messaging, these new organisations were also prepared to punish non-compliant physicians in order to ensure solidarity. In summary, they came to perform an overtly political function that differed substantially from the existing self-regulatory bodies focused on the licensing, insuring, and disciplining of members for not meeting professional standards of care and conduct. For physicians, the moral dilemma of whether a strike was consistent with their oaths to provide needed medical care to all patients was ever-present, and explains in part why physician strikes have been the exception rather than the rule in all countries. ${ }^{3}$ Finally, the fact that such collective action also went against the grain of the individualistic underpinning of medical liberalism, also explains the challenge faced by doctors in initiating and sustaining a strike.

Comparing movements or phenomena across countries, particularly when drawing lessons from history, can be hazardous unless relevant institutional differences as well as similarities are taken into account. ${ }^{4}$ One important similarity is the 'fragmented' nature of political bodies including organised medicine due to long-standing ethno-linguistic

${ }^{1}$ R.F. Badgley, 'Health Worker Strikes: Social and Economic Bases of Conflict', International Journal of Health Services, 5 (1975), 9-17.

${ }^{2}$ In the case of Australia, doctors also resorted to a strike to arrest the development of collective payment schemes through worker organisations: David G. Green, 'The 1918 Strike of the Medical Profession against the Friendly Societies in Victoria', Labour History, 46 (1984), 72-87.

${ }^{3}$ See Stephen L. Thompson and J. Warren Salmon, 'Strikes by Physicians: A Historical
Perspective Toward an Ethical Evaluation', International Journal of Health Services, 36 (2006), 331-54. On the lack of evidence concerning the postwar decline in the power of the medical profession, see David Mechanic, 'Sources of Countervailing Power in Medicine', Journal of Health Politics, Policy and Law, 16 (1991), 485-506.

${ }^{4}$ Richard Rose, Learning from Comparative Public Policy: A Practical Guide (Abingdon: Routledge, 2005). 


\section{Physician Resistance and the Forging of Public Healthcare}

divisions within the respective societies: English-French in Canada and French-Dutch in Belgium. ${ }^{5}$ Another commonality is the extent to which the medical profession has protected fee-for-service remuneration from reform efforts to adopt salary and capitation forms of remuneration in order to improve the quality of primary healthcare. As a result, the fee-for-service method of payment became embedded in the public healthcare systems of Canada and Belgium. ${ }^{6}$

There were also significant differences between the two countries in the 1960s. Canada was (and remains) a relatively decentralised federation, such that the original flashpoint for the confrontation between doctors and the state occurred in one province, although this conflict had a determinative influence on future national developments. Conversely, as a unitary state in the 1960s - Belgium only became a constitutional federation in 1993 - the conflict between organised medicine and the state was at the national level. Another important difference is the more statist nature of Canada's taxbased, governmental health system relative to Belgium's more private, though more corporatist, social insurance system. ${ }^{7}$

\section{From Ineffective Resistance to Effective Opposition, 1945-59}

The 1950s marked a critical ideological, sociological, and material transition for organised medicine in both Canada and Belgium. The medical establishment in both countries resisted key aspects of universal public healthcare. In the first phase immediately following the Second World War, this elite discovered that it had less influence in shaping public healthcare policy than it felt it deserved: organised medicine in Belgium was even barred from the negotiations that led to compulsory health insurance in 1945. As physicians improved their economic position in the post-war prosperity of the 1950s, medical organisations in both countries became more ideologically opposed to the welfare state's expansion in general, and to increasing government intervention in the funding and administration of medical care in particular.

By the late 1950s, doctors actively resisted the extension and deepening of universal healthcare policies. In Canada, a twenty-three-day strike in 1962 forced major compromises from the government, granting doctors the option to work outside the public medical care insurance scheme, and entrenching an arm's-length and contractual fee-forservice model of primary and specialised care. In Belgium, an eighteen-day strike in 1964 forced a major retreat by the Belgian government and the privileging of the feefor-service model of remuneration.

In June 1944, the first social democratic party to be elected in Canada formed the government in the province of Saskatchewan and remained in power for the next twenty

\footnotetext{
${ }^{5}$ Gregory P. Marchildon, 'Postmodern Federalism and Sub-State Nationalism', in A. Ward and L. Ward (eds), The Ashgate Research Companion to Federalism (Farnham: Ashgate, 2009), 441-55.

${ }^{6}$ On the determinative impact of major historical events on the subsequent development of public health insurance in advanced industrial nations, see Jacob S. Hacker, 'The Historical Logic of National
}

Health Insurance: Structure and Sequence in the Development of British, Canadian, and US Medical Policy', Studies in American Political Development, 12 (1998) 57-130.

${ }^{7}$ Daniel Béland and André Lecours, 'Sub-State Nationalism and Social Policy Decentralization in Canada and Belgium', Regional and Federal Studies, 17 (2006) 405-19. 


\section{Gregory P. Marchildon and Klaartje Schrijvers}

years. ${ }^{8}$ With a population of less than a million people, the majority of whom lived in medically under-serviced rural areas, the province of Saskatchewan may have seemed an unlikely candidate to initiate North America's first major experiment in universal health insurance. However, it was precisely the rural nature of Saskatchewan and the challenge in attracting physicians and providing hospital care that led to the implementation of salaried doctor schemes and publicly owned hospitals at the local government level earlier in the twentieth century. ${ }^{9}$ Moreover, T.C. (Tommy) Douglas, as the provincial head of the social democratic party (known as the Co-operative Commonwealth Federation, or CCF) and the premier of the new government, was personally committed to the incremental introduction of comprehensive public healthcare. For this reason, he assumed the additional role of health minister for the first six years of his administration. During this first period, Douglas introduced universal hospital coverage for all provincial residents. ${ }^{10}$

In 1958, Saskatchewan received shared cost financing for its hospital plan from the Government of Canada, thereby freeing the resources Douglas needed to offer universal physician care coverage. Both his cabinet and the civil service were mobilised to produce an entirely tax-funded scheme with the government acting as the single payer for all medically necessary physician services. ${ }^{11}$ However, the government faced significant opposition from doctors to this plan. While physicians had largely co-operated with the provincial government's introduction of universal hospital care insurance in the late 1940s, the profession, and the mindset of its leaders, changed dramatically during the course of the 1950s. In the 1940s, physicians supported the principle of state payment of hospital bills in part because of their own experience with destitute patients and unpaid bills during the Great Depression, when almost one-third of all provincial residents were on relief due to the collapse of the wheat-based economy. As their incomes rose in the 1950s, many doctors could not see the same benefit flowing from universal medical care insurance. ${ }^{12}$ By the end of the decade, some 250 out of the 750 practising doctors in Saskatchewan were also recent immigrants from the United Kingdom, selfstyled refugees from the National Health Service (NHS) with a deep antipathy to public healthcare. ${ }^{13}$ Saskatchewan doctors also had collective interests to protect. Through their

\footnotetext{
${ }^{8}$ Although contemporaries applied both 'socialist' and 'social democratic' labels to the CCF party and government, the Saskatchewan government was a reformist government in the tradition of social democratic and labourist governments in Europe, including the reformist-oriented Belgian 'Socialist' Party: see Seymour Martin Lipset, Agrarian Socialism: The Cooperative Commonwealth Federation in Saskatchewan (Berkeley: University of California Press, 1950), and Marcel Liebman, 'The Crisis of Belgian Social Democracy', Socialist Register, 3 (1966), 44-65.

${ }^{9}$ Clarence Stuart Houston, Steps on the Road to Medicare: Why Saskatchewan Led the Way, (Montreal: McGill-Queen's University Press, 2002), $28-40$.

${ }^{10}$ On the Saskatchewan Hospital Services Plan, see Malcolm G. Taylor, Health Insurance and Canadian Public Policy: The Seven Decisions that
}

Created the Canadian Health System, (Montreal: McGill-Queen's University Press, 1978), 69-104. ${ }^{11}$ A.W. Johnson, Dream No Little Dreams: A Biography of the Douglas Government of Saskatchewan, 1944-1961 (Toronto: University of Toronto Press, 2004), 240-1; Gregory P. Marchildon, 'Interdepartmental Committee on Medicare, 1959', Encyclopedia of Saskatchewan (Regina: Canadian Plains Research Center, 2005), 482; Vincent L. Matthews, memorandum entitled 'Extended Health Insurance - Alternate Approaches in Saskatchewan', 21 April 1959, RE679, College of Physicians and Surgeons of Saskatchewan, Saskatchewan Archives Board, Regina [hereafter SAB].

${ }^{12}$ Aleck Ostry, 'Prelude to Medicare: Institutional Change and Continuity in Saskatchewan,

1944-1962', Prairie Forum, 20 (1995), 87-105.

${ }^{13}$ Taylor, op. cit. (note 10), 265-6. 


\section{Physician Resistance and the Forging of Public Healthcare}

provincial-based organisation they were responsible for two physician-based medical care insurance carriers with 308,000 provincial residents as clients, roughly one-third of the entire provincial population. ${ }^{14}$

For historical reasons, physicians in Saskatchewan were organised differently from most provinces. ${ }^{15}$ To save money during the Great Depression, the regulatory administration (the College) was fused with the political organisation (the Association) under a single College of Physicians and Surgeons of Saskatchewan. ${ }^{16}$ This arrangement forced all members to pay dues to cover both functions, and physicians could not register any potential disagreement with the political goals and strategies of the College by opting out of the political organisation. ${ }^{17}$

In October 1959, after months of private discussions within its policy-making subcommittee, the College finally released its judgment on Douglas's plan for governmentadministered, single-payer medical care insurance. At its annual meeting on 29 October 1959 , the College passed a resolution - unanimously supported - to 'oppose the introduction of a compulsory government-controlled province-wide medical care plan, and declare our support of, and the extension of health and sickness benefits through indemnity, and service plans. ${ }^{18}$ Stating that doctors would 'not look kindly on any plan that is introduced without the say of the voters', the College demanded a province-wide referendum so that those opposed to the government plan would have ample opportunity to voice their case, arguing that many 'doctors would not work under a scheme that was brought in without a referendum.'19

On 16 December 1959, Douglas announced his government's plan to introduce a single-payer, compulsory, and universal plan, but only after consultations had been conducted by a Committee that included four physicians, three of whom were drawn from the College. He left it to this appointed Committee to design a programme that met his requirements, yet somehow be acceptable to a majority of doctors despite the growing resistance from organised medicine in Saskatchewan and the rest of Canada against single-payer, compulsory, and universal insurance plans. $^{20}$

Operating under the assumption that the College was merely negotiating for better terms under the proposed government plan with what he perceived as exaggerated

\footnotetext{
${ }^{14}$ Taylor, ibid., 261. The two physician-based insurance carriers were Medical Services Incorporated (MSI), based in Saskatoon, and Group Medical Services (GMS), headquartered in Regina.

${ }^{15}$ Of the ten Canadian provinces, only organised medicine in Alberta and British Columbia adopted the same practice as Saskatchewan for a limited time: C. David Naylor, Private Practice, Public Payment: Canadian Medicine and the Politics of Health Insurance, 1911-1966 (Montreal, McGill-Queen's University Press, 1986), 95-6.

${ }^{16}$ This arrangement - considered a conflict of interest in other jurisdictions - remained in place until the mid-1960s when criticism of the arrangement by a provincial Royal Commission led to the separation of the advocacy and trade union functions through the Saskatchewan Medical Association from the regulatory functions performed by the College. Royal
}

Commission on Hospital Privileges (Chair, Justice Mervyn Woods), Blakeney Papers, R353, 138, SAB. ${ }^{17}$ Taylor, op. cit. (note 10), 264-5.

${ }^{18}$ Resolution repeated in document 'Government in Medicine in Saskatchewan in 1960' by Dr J.F.C. Anderson, R30.1, XXVIII.1 (3 of 3), College of Physicians and Surgeons, SAB.

${ }^{19}$ Draft of news release for H. Dagliesh, 28 October 1959, R30.1, XXVIII.1, misc. files, College of Physicians and Surgeons, SAB.

${ }^{20}$ Transcript of Premier T.C. Douglas, Provincial Affairs Series, 'Prepaid Medical Care', [hereafter Douglas radio broadcast on Medicare], 16 December 1959, R33.1-575a, T.C. Douglas Papers, SAB. At the time, Douglas stated that the medical profession would have four of the ten slots on the Advisory Planning Committee, three of whom would be from organised medicine and the fourth from the College of Medicine at the University of Saskatchewan. 


\section{Gregory P. Marchildon and Klaartje Schrijvers}

rhetoric, the Douglas government continued on its course, confidant that a majority of doctors would come to accept, if grudgingly, the inevitability of universal medical care insurance. ${ }^{21}$ Douglas publicly stated that his government had 'no intention of pushing some pre-conceived plan down the doctors' throats. We want their co-operation and from our experience with other health programs I am convinced we will get it. ${ }^{, 2} \mathrm{He}$ had hoped to secure this co-operation through a representative committee, appointed by the government with College participation, mandated to provide the government with a consensus report. Instead, the College used its position on the committee to delay government action, and ultimately prepared a minority report that insisted on government subsidisation of private insurance (mainly the physician-sponsored insurance carriers) rather than the introduction of a state-sponsored single-payer plan. ${ }^{23}$

Similar miscalculations were made by the Belgian government in an effort to transform its fragmented social health insurance system into a British-style national health system in the early 1960s. The reforms targeted the five health insurance funds (mutualités) that had been transformed into compulsory funds by the Belgian government in the immediate aftermath of the German occupation during the Second World War. These funds were organised in political-ideological groupings, including Liberal, Socialist, and Christian funds. Although physicians had argued for decades in favour of neutral funds without alliances to political parties, their views were largely ignored. As a social elite, Belgian doctors resented being disregarded, but their own organisational and political weaknesses left them unable to influence the shape of the ultimate plans and prevent an erosion of their unfettered right to set their own fees. Instead, the umbrella public institution for the five funds - known as l'Assurance Maladie-Invalidité, or AMI took control of setting fees for both specialists and general practitioners.

Although there was considerable discussion about reform of Belgian social health insurance due to rising costs in the years that followed, it was not until 1959 that reforming the deficit-ridden AMI was seriously contemplated. In that year, Edmond Leburton, the new chair of the Socialist health insurance fund, began his campaign for a single, national health service similar to the NHS in Britain. In his view, there were two reasons for the growing deficits. The first was the high administrative costs associated with the division of health insurance into five separate and competitive funds. The second was the inflationary impact of fee-for-service practice. In his inaugural speech at the Socialist Party Congress in September 1959, Leburton criticised doctors as profiteers: 'I cannot help thinking they are Galeazzi-Lisi, the doctor of Pius XII, who filmed the last hours of the Pope to assure himself of a good income. How many doctors place their own ego above all considerations? ${ }^{24}$

\footnotetext{
${ }^{21}$ Allan Blakeney, An Honourable Calling: Political Memoirs (Toronto: University of Toronto Press, 2008), 49; Johnson, op. cit. (note 11), 251. As a deputy minister in the government for almost a decade, Johnson's judgment was that at the time Douglas announced Medicare 'and indeed for a long time after, the premier and ministers still believed indeed were confident - that a consensus could be achieved between them and the college.'

${ }^{22}$ Douglas radio broadcast on Medicare, 16 December 1959, R33.1-575a, T.C. Douglas Papers, SAB.
}

\footnotetext{
${ }^{23}$ Report of the Advisory Planning Committee on Medical Care to the Government of Saskatchewan Interim Report 1961 and Final Report 1962 (Regina: Department of Public Health, 1962); W.P. Thompson, Medical Care: Programs and Issues (Toronto: Clarke, Irwin, 1964).

${ }^{24}$ Recht op Gezondheid (Claims for Health), speech by Edmond Leburton given at the Socialist Party (BSP) congress of 19 September 1959, 14, Archive of the Flemish Doctors Syndicate VAS in Antwerp.
} 


\section{Physician Resistance and the Forging of Public Healthcare}

In pursuit of his dream of a Belgian NHS, Leburton persuaded Léon Servais, the Minister of Social Healthcare, to establish a parliamentary working group to re-examine the fundamental principles of public healthcare. Five members of parliament from the three major political parties (Socialist, Christian and Liberal) negotiated together. As was the case in 1945, the doctors were not consulted. ${ }^{25}$

By 1960, Belgium was suffering a recession. The government responded by tightening its belt, which triggered massive protests throughout the country. The catalyst for this upheaval was the Loi Unique (Single Law) introduced by the Christian-Liberal coalition government to counter the economic crisis. From opposition benches, the Socialist Party contested the economic measures incorporated in the Loi Unique. At the close of 1960 and beginning of 1961, riots and strikes erupted in Belgium. Despite this concerted resistance, the Loi Unique was ratified on 13 January $1961 .^{26}$ Some of the new budgetary constraints directly affected doctors. To counter the abuses of the AMI, the Loi Unique placed the five health funds under stricter administrative controls that fixed the fees for all physician consultations. Further, Article 52 of the Loi Unique stipulated that doctors who did not comply with the maximum rates would be subject to fines and, in extreme cases, jail sentences. ${ }^{27}$

Enraged by these measures, Belgian physicians founded the Contact Commission to present their complaints in a single voice to the government, but the Commission's objections were ignored. On 26 March 1961, national elections yielded a new SocialistChristian coalition government, and Leburton was appointed Minister of Social Healthcare. $^{28}$ This regime change precipitated an even more hostile relationship between the Belgian government and organised medicine. It would also signal to physicians the necessity of establishing a more effective political organisation if they were to have any chance of preventing the introduction of socialised medicine. In this, they found an ally in the Liberal Party, now in opposition to the coalition, but the doctors ultimately concluded that they needed to be prepared to go it alone in the coming struggle with the government.

\section{Mobilising Forces and Preparing for Strike}

Though not identical, the more immediate factors precipitating the mobilisation of physicians in Canada and Belgium were similar. In the Canadian case, it was the determination of the social democratic government of Saskatchewan to implement universal, single-payer medical care insurance. In the Belgian case, it was the determination of the Socialist-Christian coalition government and its Socialist minister of health to reform public healthcare without input from the medical profession. Although physicians

\footnotetext{
${ }^{25}$ Institute Emile Vandervelde, PSP Bureau 1960, 14 October 1960 and KADOC [Documentation and Research Centre for Religion, Culture and Society], LCM [Catholic Health Insurance Fund], Direction Archive, 29, Executive Committee, 13 June 1961.

${ }^{26}$ Marc Hooghe and Ann Jooris, Golden Sixties: la Belgique dans les années soixante: 1958-1973 (Ghent: Ludion-ASLK, 1999), 14.
}

\footnotetext{
${ }^{27}$ Annual Report 1960. KADOC, Archive of the Algemeen Syndicaat, Box 24; also: 'De Eenheidswet' ['Loi Unique'], Belgisch Staatsblad [Belgian Bulletin of Acts], 13 January 1961.

${ }^{28}$ Guy Vanthemsche, De Beginjaren van de Sociale Zekerheid in België. 1944-1963 (Brussels: VUB Press, 1994), 140.
} 


\section{Gregory P. Marchildon and Klaartje Schrijvers}

in Saskatchewan, assisted by the Canadian Medical Association, already had a disciplined political organisation to battle the government, physicians in Belgium had to create the political structure for waging a disciplined and effective campaign against the government. In both cases, the governments presumed that the doctors would not have the cohesiveness and discipline to conduct a sustained extra-parliamentary struggle against their respective health system reforms. To accomplish this, organised medicine in both countries employed remarkably similar strategies and tactics which included establishing: a commanding and controlling political organisation; pyramidal communications with members; public information campaigns; centralised fund raising; and effective penalties on hesitant or dissident physicians.

By the end of the 1950s, doctors in the rest of Canada realised that Saskatchewan was about to become the battleground that would determine the practice of medicine within a redesigned payment system administered by the state. As a consequence, the Canadian Medical Association (CMA), the national umbrella organisation for the provincial medical associations, provided considerable financial and in-kind support to Saskatchewan doctors in their struggle against the provincial government. ${ }^{29}$ The College spent more on the 1960 campaign than either the social democrats (known as the Co-operative Commonwealth Federation or CCF) or the opposition Liberal Party. In addition, the Ontario Medical Association - the largest and most powerful of the provincial chapters of the CMA sent its public relations guru to Saskatchewan to assist the College in its media blitz.

Indeed, the struggle in Saskatchewan was perceived to be the frontline of a larger North American war, and the American Medical Association (AMA) also provided financial support to Saskatchewan physicians. More important was what the College in Saskatchewan and the CMA learned from the AMA's experiences in its long struggle against health system reform in the United States. In particular, the College would adopt the AMA's key man system, creating cells of up to ten doctors under the control and direction of a well-known and trustworthy doctor (hence the 'key man') who would be solely responsible for receiving and sending communications up and down in the organisation. ${ }^{30}$

Premier Douglas of Saskatchewan recognised the high stakes when he restated his determination to implement universal, compulsory, single-payer medical care insurance by 1961: 'If we can do this - and I feel sure we can - then I would like to hazard the prophecy that before 1970 almost every other province in Canada will have followed the lead of Saskatchewan as we shall have national health insurance programs for [Canada as a whole]. ${ }^{31}$ Although Douglas had intended his proposed scheme of medical care insurance to be the leading issue in the provincial election of June 1960, he did not anticipate the extent to which the College was willing to turn the election into a referendum on this single issue. ${ }^{32}$

The College levied a mandatory fee of $\$ 100$ on all its members to fund its extensive public relations campaign for the election. It delivered publicity kits to all doctors to ensure

\footnotetext{
${ }^{29}$ Naylor, op. cit. (note 15), 184-5.

${ }^{30}$ Robin F. Badgley and Samuel Wolfe, Doctor's Strike: Medical Care and Conflict in Saskatchewan (New York: Atherton Press, 1967), 30 and 54.
}

\footnotetext{
${ }^{31}$ Douglas quoted in Naylor, op. cit. (note 15), $182-3$.

${ }^{32}$ Allan M. Briens, 'The 1960 Saskatchewan Provincial Election' (unpublished MA thesis: University of Saskatchewan, 2004), 30.
} 


\section{Physician Resistance and the Forging of Public Healthcare}

that the media and the public received consistent messages from its members. ${ }^{33}$ One example of the College's approach was a draft speech it sent to its members on 5 May 1960. While individual doctors had the flexibility to 'change wording' into their 'own phraseology', the College warned members 'not to stray' from the hard line message:

Saskatchewan's 930 doctors are unalterably opposed to the introduction of a government controlled compulsory prepaid medical care plan, or in plain language, state medicine. Our main reasons for opposition are based on two factors: compulsion, and government control. We are convinced that these factors would be responsible for lowering of the standards of medical care for our patients. Our position may be defined as unalterable. ${ }^{34}$

The College also purchased advertisements in local community newspapers similar to this notice in the Humboldt Journal: 'We would all like to continue practising in Humbolt as your private family physician; however, if state medicine is forced upon us by any government, you can see that we would have no choice other than to move to a province which would allow us our freedom. ${ }^{35}$

There was general approval for a tax-funded medical care insurance plan, despite a large and vocal dissenting minority - a national poll suggested that sixty per cent of Canadians supported tax-funded medical care insurance in $1960 .^{36}$ This popular support helped carry Douglas and his social democratic party to victory in the election. Believing he had received a mandate from the people of the province to move ahead with his plan, Douglas demanded a report from the deadlocked Advisory Planning Committee. Unable to defer any longer, the majority on the Committee - sympathetic to the government plan and in support of salary or capitation replacing fee-for-service remuneration - attempted a last compromise with the College minority, and accepted fee-for-service remuneration for doctors. ${ }^{37}$ Though the College representatives on the Committee acknowledged the concession, the effort ultimately produced a majority-minority report that was delivered in September $1961 .^{38}$ Beyond universal and compulsory coverage, the majority also recommended that the lion's share of funding come from general tax revenues, with only a small share raised through flat tax premium payments. ${ }^{39}$

The Douglas government responded swiftly to the report. In October 1961, the Saskatchewan Medical Care Insurance Act, 1961, was introduced into the provincial legislature without consultation with the College. Although the government had correctly determined that further negotiation with the College would only lead to further delay and deadlock, the doctors were able to point to the lack of consultation as evidence of the government's unwillingness to compromise, thereby creating a further rift between

\footnotetext{
${ }^{33}$ Naylor, op. cit. (note 15), 185-6.

${ }^{34}$ Quoted in speech by T.C. Douglas: Legislative Assembly of Saskatchewan: Debates and

Proceedings, Volume 11, 25 October 1961, 71.

${ }^{35}$ Quoted in speech by T.C. Douglas, Debates, Volume 11, 25 October 1961, 72.

${ }^{36}$ In a Gallup poll conducted in late 1960 , six out of ten Canadians supported a state-led (single-payer) medical care insurance plan 'even if this meant an increase in taxes': Naylor, op. cit. (note 15), 191.

${ }^{37}$ Douglas himself had always been willing to compromise on the issue of remuneration: Gordon S.
}

\author{
Lawson, 'The Road Not Taken: The 1945 Health \\ Services Planning Commission Proposals and \\ Physician Remuneration in Saskatchewan', Canadian \\ Bulletin of Medical History, 26 (2009), 155-87. \\ ${ }^{38}$ Thompson, op. cit. (note 23), 65; Naylor, op. cit. \\ (note 15), 193-5. \\ ${ }^{39}$ Advisory Planning Committee on Medical Care, \\ Interim Report of the Advisory Planning Committee \\ on Medical Care to the Government of Saskatchewan: \\ September 1961 (Regina: Queen's Printer, 1962).
}




\section{Gregory P. Marchildon and Klaartje Schrijvers}

the profession and the government. In the provincial legislature, Tommy Douglas led the debate on the bill, but just before the law was passed, he resigned as Premier to become the first national leader of the newly formed social democratic party - the New Democratic Party (NDP). The national NDP, coupled with its provincial branches and organised labour unions throughout Canada, now had a major political stake in successful health system reform in Saskatchewan. In the same way that the College could depend on the active support of the CMA, the insurance industry, and business lobbies throughout the country, the Saskatchewan government could rely on the national NDP and NDP oppositions to provincial governments as well as affiliated trade unions throughout Canada. $^{40}$

Woodrow Lloyd replaced Douglas as party leader and Premier of Saskatchewan. He and his newly appointed Minister of Health tried to reopen discussions with the College's leaders, but they mistook Lloyd's willingness to negotiate as an indication of weakness that only hardened their position. However, by April 1962, the Lloyd government appeared ready to give way on two key issues. In a letter to the College, Lloyd suggested that the physician-based private insurance plans might be allowed to continue under some strict understandings concerning the package of benefits, the amount assessed for premiums, and the remuneration of doctors. Second, despite his grave concerns about the potential impact on the principle of universality, Lloyd would allow doctors to opt out of the plan and directly charge patients. This was, in his own words, 'a desperate measure to prevent the threat of withdrawal of services on July 1st. ${ }^{41}$ Although the government had seemingly conceded the principle of single-payer administration, the College rejected the compromise as 'not fundamentally altering the legislation', and offered its own 'final offer'. The College insisted that the only satisfactory plan would involve government subsidies to private insurance carriers, in which doctors would be permitted to bill all patients (except indigents). ${ }^{42}$

In order to force the government to withdraw its law, the College threatened a province-wide doctors' strike. To demonstrate membership support, the College asked all available doctors in the province to attend a two-day emergency meeting in Regina in early May 1962. Almost 600 doctors - two-thirds of the province's 900 physicians closed their offices in order to attend. Realising the danger posed by organised medicine's escalating militancy, Premier Lloyd asked if he could also address the meeting: the College leaders agreed, expecting that the doctors attending would impress upon Lloyd the profession's readiness to strike if their demands were not met. The raucous, anti-government tenor of the meeting was buoyed considerably by the news that a cabinet minister - a former minister of health no less - had suddenly resigned from the government. When Lloyd took the stage, he was hissed and jeered. Immediately following Lloyd's hour-long appeal to the unreceptive audience, the College's president called for a standing vote on a motion stating physicians would refuse to practise under the

\footnotetext{
${ }^{40}$ Letter with attached pamphlet, E.P. O’Neal (Secretary-Treasurer, B.C. Federation of Labour) to W.G. Davies, 1 June 1962, R-30.1, XXVIII.1 (2 0f 9), W.G. Davies Papers, SAB.
}

\footnotetext{
${ }^{41}$ Letter, W.S. Lloyd to Rev. C. Jackson, 27 June 1962, R 30.1, XXVIII.1 (4 of 9), W.G. Davies Papers, SAB.

${ }^{42}$ Naylor, op. cit. (note 15), 200-1; letter, W.G. Davies to Rev. N.T. Quigley, 25 May 1962, R30.1, XXVIII.1 (3 of 9), W.G. Davies Papers, SAB.
} 


\section{Physician Resistance and the Forging of Public Healthcare}

government's new scheme. All but five doctors stood and applauded enthusiastically in support. ${ }^{43}$ It was now evident that a majority of doctors were prepared to go on strike.

A similar mass meeting in Brussels in 1964 would also publicise the extent to which the majority of Belgian doctors supported strike action. Unlike the situation in Canada, however, before this could occur, a more radical and pan-Belgian political organisation for doctors needed to be forged. ${ }^{44}$

It is significant that most Belgian doctors were deeply opposed to the health system reforms proposed by the new Christian-Socialist coalition, as this shared foe unified the previously fragmented profession. Although the Fédérations Médicale Belge (Belgian Medical Federation, or FMB) was a century old, it was ineffective as a political organisation because of linguistic strife and professional conflicts. For example, a separate Flemish organisation (Algemeen Syndicaat der Geneesheren van België, or AS) had been established in 1954, followed by a separate organisation for specialists that same year, and one for generalists in $1959 .{ }^{45}$ Facing Edmond Leburton as Minister of Health, Belgian physicians began to construct a more unified and organised opposition. Unable to influence the government directly, the doctors formed a new national organisation, the Association Générale des Médecins Belges (General Association of Belgian Physicians, or AGMB), that clustered the old FMB with the younger, breakaway organisations. ${ }^{46}$

In July 1961, the AGMB published a White Paper criticising the Loi Unique as well as the parliamentary working group's recommendations. The doctors also issued their own AMI reform proposal, and demanded to be involved in all future governmental deliberations on the AMI. The physician leaders also warned the parliamentary working group of the consequences that might flow from health system reforms that ignored the position of the doctors as articulated in the White Paper. ${ }^{47}$

The parliamentary working group initially dismissed the AGMB's requests, but as tensions mounted, Leburton reluctantly entered negotiations with five AGMB representatives. Surprisingly, Leburton and the five AGMB delegates reached an agreement. However, the protocol of 20 October 1961 was signed by the five AGMB negotiators without the knowledge, much less the consent, of the majority of their members. Most Belgian doctors learned of the pact through the media. ${ }^{48}$ Stunned, the doctors attacked the credibility and legitimacy of the negotiators after the public announcement. The Christian health fund also opposed the protocol because it had been excluded from the negotiations. ${ }^{49}$ These objections convinced the rest of the Cabinet to abandon Leburton by not approving the protocol. The consequences were even more severe for the future of the AGMB and its negotiators.

\footnotetext{
${ }^{43}$ Badgley and Wolfe, op. cit. (note 30$), 49$; Taylor, op. cit. (note 10), 297; W.S. Lloyd's address to the College of Physicians and Surgeons of Saskatchewan, 3 May 1962, R 30.1, XXVIII.4, Saskatchewan Medicare/College of Physicians and Surgeons of Saskatchewan, SAB.

${ }^{44}$ J.V. Craven, 'A Strike of Self-Employed Professionals: Belgian Doctors in 1964', Industrial and Labor Relations Review, 21 (1967), 18-30.

${ }^{45}$ Vanthemsche, op. cit. (note 28), 154.

${ }^{46}$ Belgian Doctors Bulletin, 23 (1960), 996-7.
}

\footnotetext{
47، Article' in Mededelingen van het Algemeen Syndicaat [Announcements of the General Syndicate], 11 January 1961, VII, 9 (KADOC, Archief Algemeen Syndicaat, Box 25).

${ }^{48}$ Protocol between the Minister of Social Healthcare and the AGMB, 20 October 1961 (KADOC, Achive General Syndicat, Box 25).

${ }^{49}$ Preparation of the law (KADOC, Archive P.W. Segers, nr. 10.8.1.3.1/1). Important representatives of this new generation were the doctors André Wynen, Roger Thoné, Toon Malfliet, Alex De Bruyn, and Mundeleer.
} 


\section{Gregory P. Marchildon and Klaartje Schrijvers}

The generational divide among Belgian doctors helped fuel a revolt within the ranks of organised medicine. A younger group of doctors rejected the old guard's leadership and its efforts to create a more effective political organisation at the national level. In 1960, the age of the typical member of this younger generation hovered around forty. Most of these doctors had been obliged to interrupt their studies because of the Second World War, when many of them were anti-German resisters in the Belgian underground or the maquis as it was known. ${ }^{50}$ These experiences would come to be formative in the decision to strike and in the deployment of effective strike tactics. ${ }^{51}$ In the summer of 1961, thirty-six of these younger doctors held two secret meetings in Luxembourg. ${ }^{52}$ These meetings would mark the beginning of a fundamental reconstitution of organised medicine in Belgium. ${ }^{53}$

While the older doctors were more amenable to working out an accommodation with the government, their junior colleagues were unwilling to compromise, preferring to launch a general strike in order to force the government to concede. To circumvent future compromise, the self-styled action committee of younger physicians prepared a letter instructing all doctors to not sign anything from the AGMB. In the view of the young activists, the time for negotiation had ended, and the time for battle had arrived. ${ }^{54}$

On 30 May 1962 the first (Liège-Luxembourg) of five syndical chambers of medicine was officially founded. ${ }^{55}$ These chambers were more overtly political and militant than any previous organisation, borrowing heavily from methods of the Belgian resistance in the Second World War. Despite their underground nature, the five chambers would

\footnotetext{
${ }^{50}$ Maquis or 'macchia' is a type of high ground covered in thick vegetation where Corsican bandits used to hide. The name was adopted by a number of underground movements in French-speaking countries.

${ }^{51}$ See on this subject André Wynen, Où allez-vous docteur Wynen? 25 ans de combat médical: le patron des médecin belges répond à Omer Marchal [Where Are You Going Dr Wynen? 25 Years of Medical Battle: The Belgian Head of Medicine Answers Omer Marchal ] (Brussels: Didier Hatier, 1989). This thesis was also confirmed by Dr Toon Malfliet (interview with Toon Malfliet by Philippe Van Meerbeeck, 1995 VRT Image Archive, for the television programme Boulevard Doctors). See also, 'Le processus de syndicalisation dans la function médicale: la constitution et le development des chambers syndicales de médecins', Courrier hebdomadaire $d u$ Centre de recherche et d' information socio-politiques [hereafter CRISP CH], 231 (1964), 12-14.

${ }^{52}$ Report SK Liège of the meeting in Marche-enFamenne 17 August 1961 and the meeting in Aarlen 28 August 1961 (Archive SK Liège).

${ }^{53}$ See Klaartje Schrijvers, 'De artsenstaking van 1964: Een studie van een conflict tussen twee elites' ['The Doctors' Strike of 1964: A Study of a Conflict Between Two Elites'] (unpublished MA thesis: University of Ghent, 2002). This research was only possible because the founder of the Syndical Chamber of Liège had preserved a large archive never
}

previously consulted. This combined with extensive interview evidence permitted a reconstruction of the Belgian doctors' strike.

${ }^{54}$ 'Prenez conscience du fait que l'heure est grave. La lutte est commencée. Ne vous trompez pas: il s'agit là d'une tentative d'étatisation!' Circular letter of the Comité Médical d'Action, Liège, 30 November 1961 (Archive Chamber Liège) and KADOC, Archive General Syndicate, Box 25. Although the structure was tempting, it took a while before the other four chambers were founded. In March 1963, André Wynen founded the chamber of HenegouwenWaals-Brabant. One of the main protagonists in the doctors' strike, Wynen also played a crucial role in the formation of the other chambers. On 31 May, Mundeleer founded the chamber of the Brussels agglomeration. In August, the chamber of AntwerpLimburg-Vlaams-Brabant and the chamber of OostWest-Vlaanderen were founded. In the meantime, a National League of Chambers was created and directed by Roger Thoné. The province of Namur joined with the creation of the Chamber Henegouwen-Waals-Brabant on 4 October See: Le processus de syndicalisation, op. cit. (note 51), $12-14$.

${ }^{55}$ Unofficially, this chamber already existed. See: Letter, W.J. Carels to liberal senator Norbert Hougardy, 24 February 1962 (Archive Chamber Liège). 


\section{Physician Resistance and the Forging of Public Healthcare}

successfully recruit a majority of doctors such that, on the eve of the 1964 strike, they represented ninety per cent of Belgian doctors. The chambers had two essential features. ${ }^{56}$ First, the members were divided into cells of ten doctors. Each cell had one representative who was in direct contact with the direction committee and acted as an intermediary. This structure was derived from the cell structure of the Belgian underground in the Second World War, inspired in turn by the communist-led partisan movement. ${ }^{57}$ Second, all critical communications were funnelled through a pyramidal telephone structure in which the chambers' leaders would communicate with the appropriate cell representative who would then relay messages to the cell members. Although personal meetings and written communications were generally avoided, any circular letters were prepared in both French and Dutch to ensure solidarity across the language divide. In addition, generalists and specialists were treated equally within the chamber.

Unlike organised medicine in Canada, previous physician organisations in Belgium did not have an expert central office to manage finances and raise external funds, or manage internal communications and external publicity. The chambers addressed this weakness by establishing a technical bureau directed by a secretary-general and staffed by lawyers, economists, tax specialists, and public relations advisors. This remarkable shift went unnoticed by the government, and cloaked the older organisations - particularly the AGMB - that continued to operate as if nothing had changed. In fact, the government upheld the status of the AGMB as the legitimate bargaining agent for doctors, even though real authority and legitimacy had shifted to the syndical chambers. In September 1962, when Leburton reopened negotiations through a new parliamentary working group, he invited the same five AGMB representatives with whom he had drafted the stillborn protocol of 1961. Moreover, when Belgian doctors formally dissolved the AGMB two months later, the government interpreted this action as an indication of fragmentation and disorganisation among physicians that could be exploited by ignoring the profession when formulating a new bill. ${ }^{58}$

The most important objective of the government was cost containment. To achieve this, the government insisted on regulating doctors' fees through a state institution, the Institut National d'Assurance Maladie-Invalidité (National Institute for Sicknesss and Disability, or INAMI). The regulations, due to come into force on 1 January 1964, stipulated that any doctors audited by the INAMI would be required to provide full information concerning their patient billings. ${ }^{59}$

When the draft bill was introduced, the chambers discovered that the five AGMB representatives had once again approved the reform. ${ }^{60}$ In its place, the chambers created a new national emergency organisation, the National Committee for Common Action (Comité National d'Action Commune, or CNAC), representing all existing medical

\footnotetext{
${ }^{56}$ Internal regulation of the SK LiègeLuxembourg, May 1962 (Archive SK Liège).

${ }^{57}$ Interview, Klaartje Schrijvers with André Wynen, 16 November 2001.

${ }^{58}$ White Paper of the AGMB, after approval of the Loi Leburton, in: Belgisch Geneesherenblad, 15: 31 August 1963, 808 (Archive VAS [Flemish Doctors' Syndicate] Antwerp).
}

\footnotetext{
${ }^{59}$ Parliamentary documents, Chamber, nr 527, i: Wetsontwerp tot instelling en organisatie van een regeling voor verplichte ZIV [Amendment for the Establishment and Organization of the Compulsory ZIV], 8 March 1963; Craven, op. cit. (note 44), 23.

${ }^{60}$ White Paper of the ABGB, after approval of the Loi Leburton, in Belgisch Geneesherenblad, 15: 31 August 1963, 807 (Archive VAS Antwerp).
} 
associations. ${ }^{61}$ Henceforth, the CNAC would be the doctors' official representative in negotiations, but still keeping the chambers largely hidden from the government. By August 1963, the new bill - known as the Loi Leburton - had been finalised. While the chambers had no interest in further negotiations, they did everything possible to delay passage and implementation of the law. Meanwhile, the government continued to negotiate with the old physician organisations, a convenient distraction while the chambers prepared their members for a nationwide strike. ${ }^{62}$ On 19 October 1963, the first mass meeting of Belgian doctors protested the Loi Leburton. More than 4,500 doctors (out of a total of 12,665 doctors in Belgium at that time) attended from every region of the country, all stating they could never agree to the Loi Leburton. ${ }^{63}$

\section{The Conduct of the Doctors' Strikes}

Governments in Canada and Belgium were unprepared for the cohesiveness and effectiveness of the doctors' strikes. Moreover, the strategies and tactics of organised medicine in both countries were similar. Doctors were organised in cells in order to facilitate rapid and confidential communications, while isolating potential dissidents and minimising their influence. They also used modern communications techniques in order to stay 'on message' when dealing with government, media, and the general public. Finally, organised medicine in both countries used social ostracism as a weapon against dissident doctors who refused to toe organised medicine's line or, even worse, engaged in active strikebreaking.

Following their mass meeting in May 1962, Saskatchewan doctors, aided and abetted by organised medicine in the rest of Canada, prepared for a general strike. The College publicly announced that, if the government did not accept its final demand for a voluntary system of private medical care insurance supplemented by public subsidy, the majority of doctors would go out on strike on 1 July $1962 .{ }^{64}$ The College's leadership selected the doctors who would exit and the doctors who would remain to provide emergency services. The College also determined which of a minority of hospitals would remain staffed with doctors, thus precipitating the temporary closure of the rest. ${ }^{65}$

Between April and July, a number of 'keep our doctors' (KOD) committees were established in order to support the doctors. Originally started by married women concerned about the possible loss of doctors in their communities and the impact this would have on their families, these KOD committees mushroomed in number and visibility in the weeks leading up to the strike. These committees may have managed to recruit almost ten per cent $\left(74,000\right.$ people) of the population by the time of the strike. ${ }^{66}$ The KOD committees were quickly infiltrated by anti-government forces including business

\footnotetext{
${ }^{61}$ Ibid., 817-820. See also Le processus de syndicalisation, op. cit. (note 51), 11.

${ }^{62}$ Guy Spitaels, 'Loi instituant et organisant un régime d'assurance obligatoire contre la maladie et l'invalidité', in Année Sociale (1963), 136-7.

${ }^{63}$ Report of the Staten-General, 19 October 1963 (Archive SK Liège).
}

\footnotetext{
64'Plebiscite Sought on Medicare', Saskatoon Star-Phoenix, 19 May 1962: R30.1, XXVIII.1 (7 of 9), W.G. Davies Papers, SAB.

${ }^{65}$ Letter, W.S. Lloyd to H. Fowler, C. Gibbings, B. Johnson, L.L. Lloyd, B. Hamilton, W. Smishek, A. Gleave and T. Beaubier, 23 May 1962, R20.1, XXVIII.1 (3 of 9), W.G. Davies Papers, SAB.

${ }^{66}$ Badgley and Wolfe, op. cit. (note 30$), 75$.
} 


\section{Physician Resistance and the Forging of Public Healthcare}

organisations, the College, as well as opposition parties. KOD rallies and meetings were held regularly in the weeks just before the strike, elevating the growing hysteria about the impending strike deadline. Although trade unions and church groups that supported the government's position began to set up their own pro-reform civil society organisations, Premier Lloyd discouraged them from engaging too visibly or directly for fear that this would simply elevate the already dangerously high level of public hysteria. ${ }^{67}$ They complied, but their absence from the field only exaggerated the anti-government voice, making the College even more confident that the government would back down on the eve of the strike, a major miscalculation. ${ }^{68}$

Realising that a strike was highly likely, the government began to recruit foreign doctors to take the places of the Saskatchewan doctors. Calculating that it could only rely on the support of between fifty and one hundred Saskatchewan doctors, and that the majority of Canadian doctors outside the province would be hesitant to provide relief because of the influence of the CMA, the Saskatchewan government began to recruit doctors abroad, particularly in the United Kingdom. Through its influential contacts in the British Medical Association (BMA), the CMA did everything it could to discourage British doctors from emigrating to Saskatchewan. On 17 May 1962, for example, the General Secretary of the CMA wrote to the Under Secretary of the BMA:

Our colleagues in Saskatchewan are as near unanimous as it is possible to be that they cannot practise under the Act and retain professional freedom. I think it would be unkind and misleading for British applicants to be subjected to these conditions of practice and I am afraid that they would be regarded as strike breakers by Saskatchewan doctors. ${ }^{69}$

The government also made emergency plans to airlift doctors from other countries, including the United States, in the event of a prolonged strike. Even before the strike, doctors began arriving from the United Kingdom, generating even more animosity between the government and the majority of doctors in the province. These new doctors also deepened the cleavage within the profession between those who supported the government and the majority against, a bitter division that was accentuated with the establishment of community clinics in those cities and towns in which pro-reform citizens opened offices for doctors who were willing to practise during the strike. To help set up the clinics, the government provided seed money to community groups to rent new offices and recruit doctors supportive of health system reform. ${ }^{70}$

Despite an attempt at mediation by the Saskatchewan Hospital Association in the last days of June, the strike began as planned on 1 July 1962. Up to this point, the events leading up to the strike had been followed closely by the provincial media and, to a lesser extent, by the media in the rest of Canada. On the first day of the strike, however, media from the rest of the world, particularly American and British newspapers, magazines, and

\footnotetext{
${ }^{67}$ Letter, W.S. Lloyd to D. Cross, 23 May 1962, R30.1, XXVIII.1 (3 of 9), W.G. Davies Papers, SAB.

${ }^{68}$ Stan Rands, Privilege and Policy: A History of Community Clinics in Saskatchewan, (Saskatoon: Community Health Cooperative Federation, 1994), 61-82.

${ }^{69}$ Quoted in letter, E. Grey-Turnor to Dr G.D. Turnor (St Andrew's Hospital, London), 26 June
}

1962, folder \#2, pamphlet file, Medical Care Prepaid, SAB.

${ }^{70}$ Letter, W.G. Davies to A. Gillanders, 29 May 1962, R 30.1, XXVIII.1 (3 of 9), W.G. Davies Papers, SAB; Gordon S. Lawson and Luc Thériault, 'Saskachewan's Community Health Service Associations: An Historical Perspective', Prairie Forum, 24 (1999) 251-68. 


\section{Gregory P. Marchildon and Klaartje Schrijvers}

medical journals had their own journalists cover the confrontation. ${ }^{71}$ In the words of the London Observer, 'Saskatchewan has become a battlefield for the whole North American continent in the struggle of the big medical organisations against "socialised medicine". ${ }^{72}$ There was a clear divide in the media with the majority of the provincial media - community newspapers and local radio and television stations - supporting the doctors, and only a minority supporting the government. In the rest of Canada, however, the majority of newspapers and the national television stations leaned in favour of the government position, arguing that the doctors had no right to strike against a democratically elected government and its decision to reform its health system. They were joined in this view by a number of international publications, including The Lancet which, while it had been sympathetic enough to the Saskatchewan doctors to bar the government from placing recruitment advertisements for British physicians to practise in Saskatchewan, nonetheless stated its objections to the College acting as a state within a state. ${ }^{73}$

As the media tide turned against the College, a small group of clerical leaders in the province met with Premier Lloyd and his inner cabinet ministers in an effort to come up with a compromise they could sell to the College in order to bring the strike to an end. Lloyd said he was still prepared to make the concessions previously offered plus other 'distinct possibilities', but in return the College had to be prepared to get its members to return to work immediately. ${ }^{74}$ However, the doctors were not prepared to consider ending the strike until after the failure of a major rally sponsored by the KOD on 11 July in front of the Legislative Assembly in the capital city of Regina. Although the KOD groups and the College had expected between 25,000 and 50,000 to come to Regina, only 5,000 people actually appeared on the day of the protest, deflating the spirit of the doctors and adding resolve to the position of the government.

At a press conference towards the end of the protest, Premier Lloyd thanked the protestors for avoiding violence even while expressing their disagreement with the government. However, he castigated the KOD for impugning the motives and competencies of doctors from the United Kingdom who had 'left busy practices at home on short notice, often at personal sacrifice' and accused the College of exercising 'its policing powers under the Medical Professions Act as an offensive weapon against practitioners who were not supporting the strike' and announced the establishment of a Royal Commission to investigate the College's actions. ${ }^{75}$

After the protest of 11 July, some physicians returned to work, and the College realised that its ability to continue the strike was waning. For its part, the government invited Lord Stephen Taylor, a physician, member of the British House of Lords, and a former Labour Party minister, to Saskatchewan to advise on a solution. Although not invited by the College, Lord Taylor quickly gained the trust of the doctors and acted as an intermediary between the College and the government. Listening patiently to the

\footnotetext{
${ }^{71}$ A.E. Blakeney, 'Press Coverage of the Medicare Dispute in Saskatchewan: I', Queen's Quarterly, 70 (1964), 352-61: 356. According to Blakeney, both The Lancet and the British Medical Journal 'condemned the doctors' strike as unethical'.

${ }^{72}$ Quoted in W.S. Lloyd's speech to CCF-NDP Convention, Saskatoon, 18 July 1962, R61.6, SAB.
}

\footnotetext{
${ }^{73}$ Blakeney, op. cit. (note 71).

${ }^{74}$ Letter, J.H. Brockelbank (Deputy Premier) to Archbishop M.C. O’Neill, 5 July 2009, R30.1, XXVIII.1 (5 of 9), W.G. Davies Papers, SAB.

${ }^{75}$ Statement by Woodrow Lloyd, Legislative Building, Regina, 12 July 1962, R30.1, XXVIII.1 (5 of 9), W.G. Davies Papers, SAB.
} 


\section{Physician Resistance and the Forging of Public Healthcare}

criticisms of the doctors and rewording the concessions previously made by the government while refusing to let either side deal with the other directly - to avoid what he felt would be inevitable misunderstandings - Lord Taylor helped facilitate a deal that became known as the Saskatoon Agreement. Signed by both parties on 23 July 1962, the compromise protected the right to fee-for-service remuneration and allowed the physician insurance carriers to process cheques - but not underwrite insurance - on behalf of doctors refusing to engage with the government directly. ${ }^{76}$ With these two concessions, the government obtained what it wanted - tax-based, universal medical care insurance. Although the doctors could argue that they had won a victory in terms of the continued legal existence of their private insurance carriers, the new payment mechanism was, in reality, a single-payer public system.

Twenty-one months after the strike in Canada, the doctors' strike in Belgium would take a very similar course, though the outcome would be interpreted very differently. As in the Canadian case, the strike focused on the new law. Though the Belgian government continued to seek the approval of physicians for the Loi Leburton, even negotiating with organisations such as the CNAC, these efforts would only backfire. Instead, physicians used these desperate efforts at conciliation to buy time to prepare for a major strike.

Despite the fact that most of organised medicine welcomed the delay, some doctors were not willing to wait. To protest the law, 1,270 doctors from Liège resigned from the Order of Doctors, preventing them from practising medicine. ${ }^{77}$ They hoped that their action would be followed in the rest of the country but they had miscalculated. Meanwhile, the leadership of the chambers realised that time was running out. It was only a matter of months, perhaps weeks, before the government realised that a doctors' strike was being planned. Once this occurred, the government was more than capable of scaring off the less militant doctors by setting out the sanctions that would be meted out to physicians who joined the strike. ${ }^{78}$ At the same time, the chambers still needed to recruit more members in regions of the country where they were weaker, particularly in Flanders.

In January, the CNAC was abolished and the five chambers went above ground as the political representative of the doctors. By the end of March 1964, following a second mass meeting of eight thousand doctors, the chambers revealed that they had recruited ninety per cent of Belgian doctors. ${ }^{79}$ The show of strength convinced the government to delay passing the bill. In a final attempt to avoid a general strike, the government held a marathon meeting with the doctors on 31 March in order to obtain a compromise, but to no avail. ${ }^{80}$ The doctors had no intention of negotiating a settlement and had

\footnotetext{
${ }^{76}$ Gregory P. Marchildon, 'Private Insurance for Medicare: Policy History and Trajectory in the Four Western Provinces', in C.M. Flood, K. Roach and L. Sossin (eds), Access to Care, Access to Justice: The Legal Debate over Private Health Insurance in Canada (Toronto: University of Toronto Press, 2005), 429-53.

${ }^{77}$ Minutes of the meeting held by the National League of SK in Brussels 4 January 1964 (Archive SK Antwerp) and Keesings Historisch Archief, 17 January 1964, 23.
}

\footnotetext{
${ }^{78}$ Letter of Dr Jous (director of the SK Liège) to Dr Alex De Bruyn (director of SK East and West Flanders), 18 December 1964. Archive SK Liège.

${ }^{79}$ René Broens, De Witte Citadel: Een verkenning van het taalgebruik van de Syndicale Artsenkamers Wynen-Henrard in de Syndicale Berichten [The White Citadel: An Exploration of the Discourse of the Syndical Doctor Chambers Wynen-Henrard in the Syndical Messages], (unpublished MA thesis: Catholic University of Leuven, 1977), 22-3 and interview by Klaartje Schrijvers with André Wynen, 16 November 2001

${ }^{80}$ De Standaard, 1 April 1964.
} 


\section{Gregory P. Marchildon and Klaartje Schrijvers}

already committed to packing their suitcases in the early hours of 1 April 1964 to leave en masse for towns just beyond the Belgian border, such as Clervaux and Mondorf in Luxembourg, Valkenburg in Holland, and Valenciennes in France. ${ }^{81}$ At four in the morning, Dr Thoné, on behalf of the five chambers, released a press statement announcing that Belgian doctors in the country had commenced 'total and unlimited strike'. ${ }^{82}$ Having managed to keep their strategy and preparations secret, the chambers quickly discovered that their general strike shocked the government, the press, and the public. ${ }^{83}$

On the ground, physicians were divided into three categories: 1) the majority who went on vacation; 2) the 'commandos' who had to remain in place in order to carry out any orders from the leadership including forcing recalcitrant doctors to go on vacation, and treating those that refused or disappeared as deserters; ${ }^{84}$ and 3 ) the 'guards' who had to remain on active duty at the hospitals in order to decide whether patients needed emergency care during the strike. The bureaux of the chambers were responsible for supervising the strike as well as co-ordinating publicity and the printing of pamphlets.

As in the Canadian case, the Belgian doctors' strike was subject to saturation reporting by the media. Each day, NIR, Belgium's public television station, broadcast daily news and images of the strike. On radio stations, proponents and opponents of the strike confronted and debated each other. Reporting constantly on the strike, the majority of newspapers - including the extensive Catholic press - took an editorial position against the strike, although a minority - in particular the liberal press - supported the doctors. ${ }^{85}$

The strike would have a direct impact on the lives of most Belgians. No longer able to consult their own physicians, they had to rely on doctors providing emergency care in hospitals. Guarding access was a physician assigned to that post by the chambers. In truth, such guards generally erred on the side of caution in terms of admitting patients. The end result was that the hospitals were overcrowded within two days of the strike. In response, the government opened the military hospitals, over which it had control, to the general population. For those Belgians who did not need or seek medical help, they nonetheless confronted a crisis atmosphere. Ambulances raced through the cities with blaring sirens while the media focused on individual incidents highlighting the danger to health and life posed by the strike. ${ }^{86}$ With little or no evidence to back up their respective claims, both sides used such incidents to prove the extent to which either the strike or the government was endangering Belgians through their respective actions. ${ }^{87}$

\footnotetext{
${ }^{81}$ See correspondence of the SK LiègeLuxembourg in the months January and February: Klaartje Schrijvers, op. cit. (note 53), 154-164.

${ }^{82}$ De Standaard, 2 April 1964.

${ }^{83}$ 'Grève Press? Bouton/Press Button Strike', undated document (Archive SK Liège).

${ }^{84}$ Some doctors admitted to the press that they joined the strike because they feared reprisals of their colleagues, see De Standaard, 2 April 1964; interview by Klaartje Schrijvers with Jef Deloof, an anti-strike doctor in Aalst who was prevented from continuing his work during the day because of regular phone calls during the night from pro-strike activists, 17 December 2000 .
}

\footnotetext{
${ }^{85}$ Quotes from Het Volk, La Libre Belgique, La Métropole, and De Nieuwe Gids in De Standaard, 2 April 1964.

${ }^{86}$ Interview with Toon Malfliet by Philippe Van Meerbeeck, 1995 VRT Image Archive, for the television programme Boulevard 'Doctors').

${ }^{87}$ Among other accidents there was the death of a child from Tongerlo on 4 April that caused a great deal of controversy. However, it could not be proven the doctors were to blame. Interview with several doctors as a result of this accident, in: VRT Radioarchive, MGT54771, nr. 3, 6 April 1964.
} 


\section{Physician Resistance and the Forging of Public Healthcare}

Despite public pressure on both sides, the reopening of negotiations seemed impossible in the first week of the strike. Both sides issued ultimatums, the government insisting that it would only negotiate once the doctors returned to work, and doctors insisting on major revisions to the law before they would call an end to the strike. Then, on 9 April, the rectors of the four Belgians universities intervened, offering to mediate in an effort to trigger negotiations. The parties agreed to sit down and talk on the weekend of 11-12 April but this first effort failed due to one careless remark to the media by Prime Minister Théo Lefèvre: 'J'espère que l'on ne devra pas appeler ce temps, le temps des assassin' ['I hope we will not have to call this period, the time of assassins']. ${ }^{88}$ When this comment was passed on to all doctors by telephone, they threatened to abolish guard duties at the hospital in retaliation. ${ }^{89}$

In response, the government panicked, and drew up new military guidelines facilitating the conscription of doctors in order to bring the strike to a rapid end. The new orders demanded that all doctors who were part of the Belgian military reserve had to report in uniform - to their respective commanding officers in order to be assigned for hospital duty. Doctors who refused to report for duty were subject to severe fines. In response, the five chambers advised the doctors being called up not to obey orders that were meant to sabotage the strike. ${ }^{90}$

The government's desperate ploy marked a turning point in the strike. Although its position had initially been accepted by a majority of the public and media, the national government faced increasing criticism as the strike continued. At the same time, however, the pressure of the strike began to produce cracks within the leadership and among the membership of organised medicine. In particular, there emerged a sharp conflict about the objective of the strike. For some, the purpose was to achieve their objective in ensuring that any health system reform did not change existing freedoms in terms of billing. For others, the objective was to bring down the government itself.

These weaknesses pushed both sides back to the bargaining table with the four university rectors the following weekend, 17-18 April, at the end of which the government retreated on its position and the doctors agreed to end the strike. ${ }^{91}$ Since the weekend settlement met most of the doctors' demands, it was interpreted as a victory for the chambers and a major defeat for the government. ${ }^{92}$ However, as in the case of Canada where the opposite was perceived to have occurred, the long-term consequences were more nuanced and less favourable to the perceived victors.

\section{Conclusion and Consequences}

The leaders of organised medicine in Canada and Belgium shared a very similar philosophy. Both versions of medical liberalism defended the right of doctors to determine the nature of their relationship with patients, especially their untrammelled right to set their own fees, and attacked more collectivist philosophies that viewed healthcare as a

\footnotetext{
${ }^{88}$ Archive RTBF (the French speaking public television station), documentary 'Médecins en colère' in the series Années belges, 31 March 1998.

${ }^{89}$ Speech of minister Piet Vermeylen, 12 April 1964, MGT 54771, nr. 4. VRT Radio-archive.
}

\footnotetext{
${ }^{90}$ Mots d'ordre of the strike committee of the SK Liège-Luxembourg, 13 Apr. 1964. Archive SK Liège.

${ }^{91}$ De Standaard, 17 April 1964

${ }^{92}$ VRT Radio-archive, MGT 54817, nr. 3, 1964 April 18 and De Standaard, 20 April 1964.
} 


\section{Gregory P. Marchildon and Klaartje Schrijvers}

public good and right of citizenship rather than a market service provided by physicians to clients or consumers. Rooted in a nineteenth-century conception of the freedom to contract and a limited state, the tenets of medical liberalism clashed with the more collectivist philosophies propounded by social democratic, democratic (non-revolutionary) socialist, and similar centre-left political movements in the twentieth century.

The 1960s marked the apex of the expansion of the welfare state in the advanced industrial countries of the West, an expansion led by centre-left governing parties that promoted universal access to medical services. While this trend was resisted by organised medicine in numerous countries, the most formidable resistance came in the form of the lengthy and bitter doctors' strikes in Canada and Belgium. These respective strikes would mark both polities and shape the evolution of public healthcare in the future by ensuring that doctors remained private, independent contractors with the state. In both countries, fee-for-service remuneration remains the dominant system of payment for physicians, and a semi-permanent obstacle to government-led reforms of primary healthcare. These longer-term consequences seem to clash with more contemporary evaluations of the outcomes of the strike in both countries.

In Canada, the government was generally perceived to have won the strike. However, in reality, organised medicine was able to improve the economic position of its members even while it preserved the contractual system of remuneration and private practice, protected the role of physicians at the centre of the healthcare system, and prevented major changes to primary healthcare. ${ }^{93}$ In a manner similar to the British Medical Association's ability to exploit divisions within successive British governments, the Canadian Medical Association and its provincial chapters were effective in consolidating their gains and preventing subsequent governments from initiating further reform, in part because of the fear of another strike by physicians. ${ }^{94}$

In Belgium, the doctors were perceived to have won the strike. In an important sense, this was an accurate perception in that Belgian physicians, like their Canadian counterparts, preserved the contractual system of fee-for-service remuneration and private practice and protected the role of physicians as the central players in the Belgian health system. In particular, organised medicine in Belgium had prevented a British-style national health system from being erected. However, unlike the Canadian case, the doctors were unable to prevent the Belgian government from placing controls on physician remuneration in order to contain cost, and in this respect, could not supplant the continued supremacy of the social insurance funds.

\section{Acknowledgements}

The authors would like to thank the journal's two anonymous referees and Roger Cooter for their valuable insights as well as John Nilson, Angela Scott, and Gordon Lawson for their comments and suggestions on an earlier version of the manuscript.

\footnotetext{
${ }^{93}$ J.W. Gouldner, 'Why the Doctors Lost their Strike', Society, 3, 4 (1966), 14-18.

${ }^{94}$ John Stewart, 'Ideology and Process in the Creation of the British National Health Service', Journal of Policy History, 14, 2 (2002) 113-34;
}

\author{
Carolyn Hughes Tuohy, Accidental Logics: The \\ Dynamics of Change in the Health Care Arena in the \\ United States, Britain, and Canada (Oxford: Oxford \\ University Press, 1999), 37-61.
}

